\title{
PERAN ZINC DALAM PROSES LAKTASI
}

\author{
Thontowi Djauhari Nur Subchi \\ Mahasiswa Program Doktor Fakultas Kesehatan Masyarakat Universitas Airlangga \\ Email : thontowi@umm.ac.id
}

\begin{abstract}
ABSTRAK
Zinc adalah trace element diperlukan untuk berbagai proses metabolisme termasuk mengatur protein yang terlibat dalam sintesis DNA, protein serta mitosis. Selain mengatur fungsi seluler dasar pengaturan transport zinc di glandula mammae sangat penting untuk mencukupi kebutuhan Air Susu Ibu ( ASI ) selama menyusui. Transfer zinc yang adekuat ke dalam susu penting untuk kebutuhan zinc neonatus selama pertumbuhan dan perkembangan. Defisiensi zinc pada bayi akan menyebabkan gangguan fungsi imunitas dan perlambatan pertumbuhan. Pengaturan mekanisme transport zinc sangat penting untuk menyediakan zinc yang disekresikan ke dalam ASI serta menjaga fungsi sel yang optimal di glandula mammae.
\end{abstract}

Kata Kunci : Zinc, Laktasi

\section{ABSTRACT}

Zinc is a necessary ingredient including regulating proteins involved in DNA synthesis, protein and mitosis. In addition to regulating basic cellular functions, zinc transport arrangements in the mammary gland are essential to meet the needs of breastfeeding during breastfeeding. Adequate zinc transfer into milk is important for neonates zinc requirements during growth and development. Zinc deficiency in infants will lead to impaired immune function and growth retardation. The arrangement of the zinc transport mechanism is essential for providing the secreted zinc into breast milk and maintaining optimal cell function in the mammary glands.

Keyword : Zinc, Lactation

\section{PENDAHULUAN}

Pemberian ASI eksklusif didefinisikan sebagai praktek memberikan ASI kepada bayi selama enam bulan pertama kehidupan dan tidak ada makanan atau air yang lainnya. Kekurangan ASI memiliki dampak pada jumlah kematian bayi. Praktek menyusui yang optimal dan juga inisiasi ASI dalam satu jam kehidupan serta menyusui hingga usia 2 tahun atau lebih membantu meningkatkan immunitas bayi. Pemberian ASI eksklusif adalah landasan kelangsungan hidup bayi dan kesehatan anak karena menyediakan nutrisi penting yang tak tergantikan untuk pertumbuhan dan perkembangan anak. ASI juga berfungsi sebagai imunisasi pertama bayi dan memberikan perlindungan dari infeksi saluran pernafasan, penyakit diare dan penyakit yang berpotensi membahayakan jiwa lainnya. Pemberian ASI eksklusif juga memiliki efek perlindungan terhadap obesitas dan penyakit tidak menular tertentu di kemudian hari (B. L. Horta, 2013)

Banyak masalah yang harus dilakukan untuk pemberian ASI eksklusif selama 6 bulan pertama kehidupan sebagai norma untuk pemberian makan bayi. Dilaporkan hanya 38\% bayi usia 0 hingga 6 bulan yang mendapat ASI eksklusif (R. E. Black et al., 2013. World Health Organization, 2013). Analisis terbaru menunjukkan bahwa praktik menyusui yang kurang optimal, termasuk pemberian ASI noneksklusif berkontribusi pada 11,6\% kematian pada anak di bawah usia 5 tahun. Data ini setara dengan sekitar 804.000 kematian anak pada 2011 (E. Black et al.,2013). Dilaporkan adanya peningkatkan pemberian ASI eksklusif. Antara 1985 dan 1995, 
ditingkat global pemberian ASI eksklusif meningkat rata-rata 2,4 persen per tahun, meningkat dari 14 persen menjadi 38 persen selama 10 tahun. Dilaporkan 25 negara meningkat pemberian ASI eksklusif mereka sebesar 20 persen atau lebih setelah tahun 1995, angka tersebut dipacu untuk mencapai target global (UNICEF, 2013. World Health Organisation, 2015)

Data Polman, menunjukkan bahwa berdasarkan hasil penelitian World Breastfeeding Trends Initiative (2013), hanya 27,5 persen ibu di Indonesia yang berhasil memberi ASI eksklusif selama 6 bulan. Data Riset Kesehatan Dasar 2013 menunjukkan cakupan ASI di Indonesia hanya 42 persen. Dari hasil tersebut, Indonesia berada di peringkat 49 dari 51 negara yang mendukung pemberian ASI eksklusif.

Zinc mengatur fungsi hampir 100 enzim berbeda, DNA dan Sintesis RNA, metabolisme karbohidrat, homeostasis asam-basa, absorpsi folat, vitamin $A$ dan mengaktifkan vitamin $D$ sertamempertahankan stabilitas membran sel. (Khayat, 2017). Sumber zincterbanyak adalah kerang, daging, telur, biji-bijian, kacang tanah, produk susu, gandum dan Sayuran hijau (G. Caja, 2014). Bijibijian memiliki konsentrasi zinc yang rendah, dilaporkan populasi yang memiliki diet berbasis protein gandum mengalami defisiensi zinc. (Khayat, 2017). Zinc memainkan peran penting dalam kehamilan dan menyusui, termasuk perkembangan janin dan sekresi ASI. Bioavailabilitas zinc dalam diet diperlukan selama kehamilan untuk memenuhi kebutuhan fisiologis. (K. H. Brown et al., 2004)

Zincadalah modulator kunci dari biologi glandula mammae dan sangat penting untuk keberhasilan laktasi. Zinc mengatur transkripsi gen, perkembangan sel-sel dan apoptosis, yang penting dalam mengatur pembaruan laktosit. Pengembangan sel alveolar dan diferensiasi fungsional menjadikan sel mensekresi ASI yang diatur oleh zinc. Zincpenting untuk aktivitas struktural, katalitik dan pengaturan untuk sintesis dan mensekresi ASI. (S. Lee, 2016)

Laktasi memberikan banyak manfaat kesehatan bagi bayi yang menyusui dan ibu menyusui. Agar berhasil menyusui, glandula mammae harus berkembang dan berdiferensiasi untuk mengaktifkan banyak proses yang mengatur produksi dan mensekresi ASI. Proses ini melibatkan serangkaian kompleks peristiwa molekuler, biokimia dan seluler yang sebagian besar didorong oleh hormon laktogenik. Dilaporkan dalam penelitian terbaru pengaruhzinc sebagai modulator penting untuk mengaktifkan fungsi glandula mammae. Disini dilaporkan temuan baru tentang peran dan regulasi seng dalam membantu proliferasi, diferensiasi dan sekresi di glandula mammaeselama menyusui.

Prolaktin (PRL) adalah hormon pengikat zinc yang umumnya diperlukan untuk inisiasi dan pemeliharaan laktogenesis. Zinc diduga berperan dalam proses sintesis, penyimpanan, dan sekresi PRL dari hipofisis anterior, mulai dari pengaturan ekspresi gen hingga penghambatan pengikatan enzim dan granula sekretorik (.M. Y. Lorenson, 1996) Penelitian Lorenson dan kawan-kawan mengatakan, PRL disimpan sebagai oligomer stabil yang mengandung zinc. Penghilangan zinc diperlukan untuk konversi ikatan disulfida intermolekul menjadi ikatan disulfida intramolekul, sebagai langkah yang diperlukan untuk monomerisasi dan sekresi berikutnya (S. Khayat, 2017) Peningkatkan ketersediaan zincakan menghambatpembentukan dan sekresi PRL monomer dari hipofisis anterior. Beberapa penelitian in vitro telah dilaporkan efek konsentrasi zinc pada sekresi PRL dari kelenjar pituitari anterior. (J. Brandão-Neto, 1995)

Tubuh manusia mengandung sekitar 2 gramzinc secara total, dengan 60 persen ditemukan di otot rangka dan 30 persen dalam massa tulang, selain itu juga ditemukan di semua jaringan tubuh dan cairan. Wanita dewasa perlu $12 \mathrm{mg}$ zinc per hari dan wanita hamil dan menyusui membutuhkan hingga $14 \mathrm{mg}$ zinc per hari. Tingkat asupan ini umumnya tidak dapat dipenuhi di negara berkembang karena diet kurang asupan kalori dari biji-bijian dan makanan pokok lainnya. (S. Hussain, 2010). Review ini bertujuan untuk menunjukkan pentingnya peran zinc dalam pembentukan ASI di glandula mammae dan pentingnya asupan zinc selama masa hidup.

\section{Seng dan Kelenjar Susu}

Glandula mammae adalah jaringan sekretorik yang membutuhkan zincuntuk proses biologis tertentu yang sangat penting untuk fungsi jaringan. Peran zinc dalam glandula mammae bersifat multifaset, karena glandula mammae adalah jaringan dinamis yang mengalami perubahan morfologis dan fungsional. Diperlukan upaya terkoordinasi untuk menyediakan zinc yang cukup untuk ekspansi jaringan selama laktasi, dimana 
jaringan glandula mammae secara efisien akan diperbaiki setelah penyapihan. Memahami mekanisme pengaruh zincyang mengatur proses ini sangat penting untuk memahami fisiologi glandula mammae. Peran khusus untuk zinc penting dalam pengaturanglandula mammae, remodelling, dan laktasi, dan penyakit payudara (S. L. Kelleher, 2011). Secara struktural, glandula mammae terdiri dari jaringan duktus alveolus yang berakhir pada unit terkecil yang disebut asinar. Setiap asinar dilapisi dengan Sel Epitel Mammae (SEM) yang bertanggung jawab untuk memindahkan nutrisi ke dalam ASI selama laktasi. Dari perspektif ini, SEM adalah pusat produksi ASI dimana mereka mengaturfungsi regulasi proliferasi SEM dan diferensiasi sel. Zincmengatur proliferasi sel, khususnya melalui perannya dalam mengatur ekspresi gen. (B. L. Bohnsack, 2004) Dengan demikian, pengaturan yang tidak efektif dari faktor transkripsi dapat menyebabkan hiperproliferasi atau hiperproliferasi SEM. Masih sedikit informasi tentang mekanisme khusus di mana zinc mengatur perkembangan glandula mammae, tetapi data yang ada menunjukkan bahwa zinc secara spesifik memainkan peran penting dalam faktor transkripsi. Zinc yang telah terlokalisasi di sitoplasma akan mengekspresikanglandula mammae, dan ekspresi ini terbatas pada tahap perkembangan proliferasi SEM aktif dan pengembangan kelenjar lobulo-alveolaratau kelenjar asinar (J. Singh, 2001)

Gambar 1.

Proliferasi SEM aktif dan pengembangan kelenjar asinar.

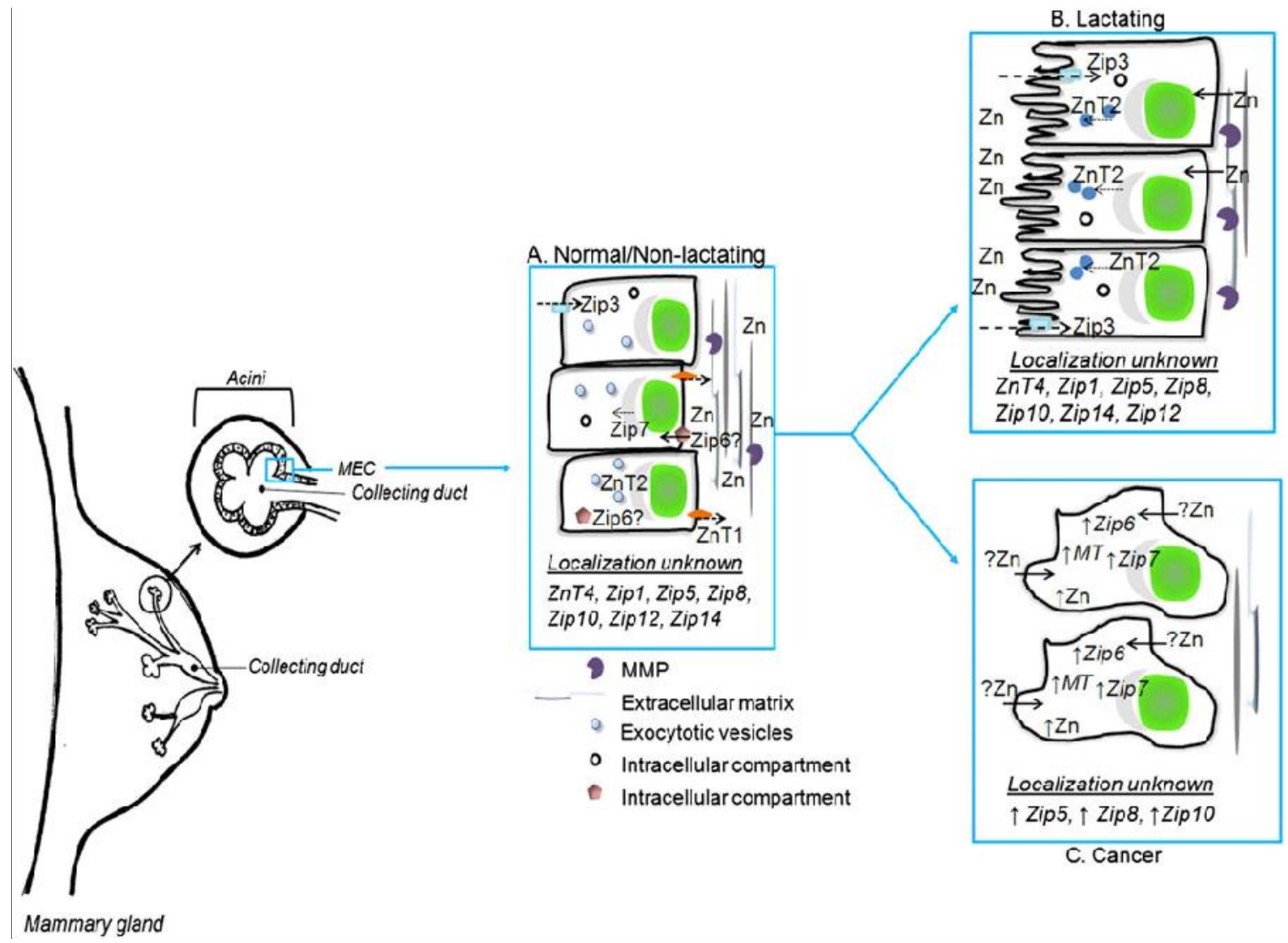


(A) Zinc dan zinctranspoter terlibat dalam mengatur fungsi glandula mammae yang terdiri dari jaringan struktur duktus alveolar dan berakhir pada sel asinar yang dikenal sebagai lobulus. SEM bertanggung jawab untuk produksi dan sekresi ASI ke dalam duktus kolektivus untuk persiapan menyusui. Diperlukan Zip3 dan ZnT2 selama kondisi normalatau nonlaktasi, ZnT4 akan membantu mengekspresikan produksi susu. Zip6 dan Zip7 diekspresikan dalam sel asinar. (B) Selama menyusui, ZnT2 memainkan peran utama dalam sekresi zinc ke dalam ASI, sementara Zip3 memainkan peran dalam re-uptakezincdari lumen. Kontribusi zinc transporter selama diferensiasi dan laktasi SEMmemegang peran penting untuk proses laktasi. (C) Hyper-akumulasizinc telah dikaitkan dengan $\mathrm{Ca}$ mammae. Diketahui zinc transporter seperti (Zip5, Zip6, Zip7, Zip8, dan Zip10) telah terbukti meningkat pada kasus $C a$. mammae.

Beberapa penelitian memberikan bukti struktural dan fungsional bahwa varian genetik umum di Zn'T2 dapat mempengaruhi fungsi seluler utama dalam SEM. Dari penelitian didapatkan bahwa ibu yang menerima asupanseng yang berlebihan akan mengekspresikan faktor molekuler dalam glandula mammae yang menyebabkan stres oksidatif di mammae. Kelainan molekuler diketahui secara in vitro mengindikasikan peningkatan fosforilasi dan mislokalisasi seng kedalam Retikulum Endoplasmik dan lisosom berhubungan dengan stres oksidatif, gangguan fungsi paraseluler, dan kematian sel yang dimediasi oleh lisosomal. Varian genetik dalam ZnT2 memiliki konsekuensi pada sub-seluler $Z n$ pools dan fungsi molekular SEM dimana akan menyebabkan disfungsi glandula mammaedan kinerja laktasi yang buruk.Dilaporan bahwa variasi genetik dapat menyebabkan kinerja laktasi yang sub-optimal, dan studi lebih lanjut untuk dilaporkanterdapat efek variasi genetik pada fungsi mammae (S. Lee, 2018)

\section{Laktasi}

Laktasi memberikan banyak manfaat kesehatan bagi bayi dan ibu menyusui. Agar berhasil menyusui, glandula mammae harus berkembang dan berdiferensiasi untuk mengaktifkan banyak proses yang mengatur produksi dan sekresi ASI. Peristiwa ini melibatkan serangkaian peristiwa molekuler, biokimia dan seluler yang sebagian besar diatur oleh hormon laktogenik. Telah diketahui zinc sebagai modulator penting dari fungsi glandula mammaedalam meningkatkan proliferasi, diferensiasi dan sekresi di glandula mammae selama menyusui.

Zinc diperlukan dalam metabolisme dan laktasi di glandula mammae untuk memberikan zinc yang optimal pada bayi. Glandula mammae harus mengimpor sejumlah besar zinc dari sirkulasi ibu dan kemudian mensekresikannya ke dalam glandula mammae sekitar 0,5-1 mg zinc per hari. Proses ini hampir dua kali jumlah zinc yang ditransfer setiap hari dari plasenta ke janin selama trimester ketiga kehamilan (J. C. Ki ng, 2002). Pentingnya asupan zinc yang optimal selama periode neonatal dibuktikan dengan kematian neonatal terkait dengan kadar zinc ASI yang rendah pada tikus percobaan (L.Huang, 1997)

Disregulasi proses pada manusia juga menghasilkan kondisi yang disebut sebagai "kekurangan zincneonatal sementara" yang menyebabkan defisiensi zinc berat pada bayi yang menyusui. Beberapa penelitian menunjukkan bahwa proses mengangkut dan mengatur perpindahan zinc tergantung pada integrasi yang erat dari mekanisme pengangkutan zinc sehingga memastikan zinc terserap ke dalam glandula mammae dikeluarkan secara optimal ke dalam ASI. Penelitian untuk mengetahui beberapa peran transporter zinc (Zip1, Zip3, ZnT1, ZnT2, dan ZnT4) telah memberikan informasi awal mengenai mekanisme yang mengatur tingkat zinc ke dalamASI. Sebagian penelitian yang dilakukan pada tikus menyusui atau model sel mammae. Menunjukkan Zip1 diekspresikan dalam glandula mammae mamalia tikus, melintasi membran luminal dari glandula mammae yang terkumpul dalam lumen alveolarglandula mammae.(S. L. Kelleher, 2009)

ZnT1 berhubungan dengan membaran luminal selama awal laktasi yang dideteksi didalam sel mammae. ZnT2 terlokalisasi di bagian proximal membrane luminal sel epitel mammae. (J. P. Liuzzi, 2004) ZnT2 memainkan peran penting dalam memediasi transfer zincke dalam susu selama awal laktasi.(J. P. Liuzzi, 2004) Ekspresi Zn'T2 diatur oleh hormon laktogenik sebagai hasil dari regulasi transkripsi melalui mekanisme pensinyalan prolaktin.(L.Qian, 2009). Di glandula mammae, ZnT4 paling melimpah di sel di sekitar duktus 
alveolar dan berada dalam kompartemen intraseluler tetapi tidak berkumpul secara bersamaan dengan kumpulan zinc yang tidak stabil.(A. A. Michalczyk, 2002) Peran ZnT4 dalam ASI akan mensekresi zinc yang berhubungan dengan pengurangan sekresi zinc ke dalam ASI selama laktasi.(J. P. Liuzzi, 2004)

Singkatnya, glandula mammae adalah jaringan responsif hormonal yang sangat khusus dan memiliki persyaratan spesifik tentang seng yang dihasilkan dari kebutuhan untuk mengambil, mendistribusikan ulang dan mengeluarkan jumlah zinc yang banyak ke dalam ASI untuk memberikan zinc yang optimal kepada bayi yang baru lahir. Pemisahan dari proses ini selama laktasi menghasilkan defisiensizinc neonatus yang berat dimana digambarkan pentingnya pengaturanyang ketat mekanisme transpor zinc pada glandula mammae. Lebih lanjut, kegagalanmekanisme pengangkutan zinc pada glandula mammaewanita tidak menyusui dapat menyebabkan perkembangan Ca. mammae. Hubungan antara kegagalan mekanisme transpor zinc dan Ca. mammaeperlu penelitian lebih lanjut.(L. Qian, 2009)

Konsep jaringan transportasi zinc relatif baru, dinamis, dan terus berkembang. Saat ini ada 24 transporter $Z n$ yang dikenal yang terdiri dari dua keluarga: Zip dan ZnT atau disebut Zn transporter. Ada 14 protein Zip (Zip1 - Zip14) dan $10 \mathrm{ZnT}$ protein (ZnT1 - ZnT10) yang cara kerja dan ekspresinya bervariasi pada setiap tingkat organisasi biologis. Glandula mammae memanfaatkan sebagian besar pengangkut zinc untuk mengatur berbagai fungsi penting. Sampai saat ini, hanya dua transporter zinc telah ditunjukkan untuk mengatur peran sentral dalam fungsi glandula mammae yaitu ZnT2 dan ZnT4 (V. Lopez, 2009)

ZnT2 diekspresikan dalam beberapa jaringan termasuk glandula mammae, prostat, usus kecil, hati, ginjal dan monosit.(L. A. Lichten , 2009) Beberapa penelitian menunjukkan bahwa ZnT2 terlibat langsung dalam transfer zinc ke dalam ASI selama laktasi. Pada sel epitel mammae, dua isoform ZnT2 berbeda secara diferensial terlokalisir pada vesikula eksositosis dan membran sel, (V. Lopez, 2009) keduanya secara fungsional mengangkut zinc. Selain itu, overekspresi ZnT2 dalam sel memberikan tingkat resistensi toksisitas zinc. Selain itu polimorfisme nukleotida tunggal non-identik dalam ZnT2 menghasilkan sekresi zinc yang terdegredasi dan meningkatkan stres oksidatif pada sel-sel epitel kelenjar mammae (Y. A. Seo, 2010). ZnT2 secara transkripsi diatur oleh hormon laktogenik PRL, dan kelebihan ZnT2 akan meningkatkan zinc empat kali lipat dalam glandula mammaeketika fase menyusui dibandingkan dengan jaringan nonlaktasi (L. Qian, 2009)

Kondisi di glandula mammae, ZnT4 telah terlokalisir di membran apikal epitel susu, dan kelebihan ZnT4 secara signifikan lebih tinggi dalam glandula mammae selamafase menyusui dibandingkan dengan fase tidak menyusui, (S. L. Kelleher,2012) ini menunjukkan peran penting untuk transportasi zinc ke dalam ASI selama laktasi. Selain itu, jumlah ZnT4 akan menurun sepanjang perjalanan laktasi, analog dengan konsentrasi zincdi dalam ASI akan menunjukkan peran ZnT4 dalam mentransfer zinc ke dalam ASI untuk bayi yang sedang berkembang. (S. L. Kelleher, 2003). Secara fisiologis ZnT4 akan meningkatkan produksi ASI sehingga akan meningkatkan kesehatan bayi.

\section{KESIMPULAN}

Glandula mammae adalah jaringan sekretorik lain yang membutuhkan zinc untuk proses biologis tertentu dalam mempengaruhi pembentukan ASI. Peran zinc dalam glandula mammae bersifat multifaset, karena glandula mammae adalah jaringan dinamis yang mengalami perubahan morfologis dan fungsional secara dramatis. Diperlukan koordinasi yang baik untuk menyediakan zinc yang cukup selama laktasi. Disimpulkan zinc berperan dan bertanggung jawab untuk transkripsi RNA sehingga menyebabkan hiperproliferasi SEM dan berpengaruh pada pengembangan sel asinar dalam memproduksi ASI.

\section{REFERENSI}

A. A. Michalczyk, J. Allen, R. C. Blomeley, and M. L. Ackland, "Constitutive expression of hZnT4 zinc transporter in human breast epithelial cells," Biochem. J., vol. 364, no. Pt 1, pp. 105-113, 2002.

B. L. Bohnsack and K. K. Hirschi, "NUTRIENT REGULATION OF CELL CYCLE 
PROGRESSION," Annu. Rev. Nutr, vol. 24, pp. 433-53, 2004.

B. L. Horta and C. G. Victora, "Long-term health effects of breastfeeding.," World Heal. Organ., vol. 129, no. 8-9, pp. 57-64, 2013.

G. Caja, Nutrition During Lactation (1991).pdf, no. June. 2014.

G. Jones, R. W. Steketee, R. E. Black, Z. A. Bhutta, and S. S. Morris, "How many child deaths can we prevent this year?," Lancet, vol. 362, no. 9377. pp. 65-71, 2003.

I. Wattimena and Y. Dwi, "Manajemen Laktasi dan Kesejahteraan Ibu Menyusui," J. Psikol., vol. 42, no. 3, pp. 231-242, 2015.

J. Brandão-Neto, G. Madureira, B. B. Mendonça, W. Bloise, and A. V. B. Castro, "Endocrine interaction between zinc and prolactin - An interpretative review," Biological Trace Element Research, vol. 49, no. 2-3. pp. 139-149, 1995.

J. P. Liuzzi, J. a Bobo, L. Cui, R. J. McMahon, and R. J. Cousins, "Zinc transporters 1,2 and 4 are differentially expressed and localized in rats during pregnancy and lactation.," $J$. Nutr., vol. 133, no. 2, pp. 342-351, 2003.

J. P. Liuzzi, J. A. Bobo, L. A. Lichten, D. A. Samuelson, and R. J. Cousins, "Responsive transporter genes within the murine intestinalpancreatic axis form a basis of zinc homeostasis.," Proc. Natl. Acad. Sci. U. S. A., vol. 101, no. 40, pp. 14355-14360, 2004.

J. Singh, Y. Itahana, S. Parrinello, K. Murata, and P. Y. Desprez, "Molecular cloning and characterization of a zinc finger protein involved in Id-1-stimulated mammary epithelial cell growth.," J. Biol. Chem., vol. 276, no. 15, pp. 11852-8, 2001.

J. C. King, "Enhanced zinc utilization during lactation may reduce maternal and infant zinc depletion," American Journal of Clinical Nutrition, vol. 75, no. 1, pp. 2-3, 2002.

K. H. Brown et al., "International Zinc Nutrition Consultative Group (IZiNCG) technical document \#1. Assessment of the risk of zinc deficiency in populations and options for its control.," Food and nutrition bulletin, vol. 25, no. 1 Suppl 2. 2004.

L. Huang and J. Gitschier, "A novel gene involved in zinc transport is deficient in the lethal milk mouse," Nat. Genet., vol. 17, no. 3, pp. 292-297, 1997.

L. Qian, V. Lopez, Y. A. Seo, and S. L. Kelleher, "Prolactin regulates ZNT2 expression through the JAK2/STAT5 signaling pathway in mammary cells.," Am. J. Physiol. Cell Physiol., vol. 297, pp. C369-C377, 2009.

L. A. Lichten and R. J. Cousins, "Mammalian Zinc Transporters: Nutritional and Physiologic Regulation," Annu. Rev. Nutr., vol. 29, no. 1, pp. 153-176, 2009.

M. Y. Lorenson, T. Patel, J. W. Liu, and A. M. Walker, "Prolactin (PRL) is a zinc-binding protein. I. Zinc interactions with monomeric PRL and divalent cation protection of intragranular PRL cysteine thiols," Endocrinology, vol. 137, no. 3, pp. 809-816, 1996.

R. E. Black et al., "Maternal and child undernutrition and overweight in low-income and middleincome countries.," Lancet, vol. 382, no. 9890, pp. 427-51, 2013.

S. Hussain, M. A. Maqsood, and Rahmatullah, "Increasing grain zinc and yield of wheat for the developing world: A Review," Emirates J. Food Agric., vol. 22, no. 5, pp. 326-339, 2010.

S. L. Kelleher, N. H. McCormick, V. Velasquez, and V. Lopez, "Zinc in Specialized Secretory Tissues: Roles in the Pancreas, Prostate, and Mammary Gland," Adv. Nutr. An Int. Rev. J., vol. 2, no. 2, pp. 101-111, 2011.

S. L. Kelleher, Y. A. Seo, and V. Lopez, "Mammary gland zinc metabolism: regulation and dysregulation," Genes Nutr., vol. 4, no. 2, pp. 83-94, 2009.

S. Lee, Y. Zhou, D. L. Gill, and S. L. Kelleher, "A genetic variant in SLC30A2 causes breast dysfunction during lactation by inducing ER stress, oxidative stress and epithelial barrier defects," Sci. Rep., vol. 8, no. 1, 2018. 
S. L. Kelleher, V. Velasquez, T. P. Croxford, N. H. McCormick, V. Lopez, and J. Macdavid, "Mapping the zinc-transporting system in mammary cells: Molecular analysis reveals a phenotype-dependent zinc-transporting network during lactation," J. Cell. Physiol., vol. 227, no. 4, pp. 1761-1770, 2012.

S. L. Kelleher and B. Lönnerdal, "Zn transporter levels and localization change throughout lactation in rat mammary gland and are regulated by $\mathrm{Zn}$ in mammary cells.," J. Nutr., vol. 133, no. August, pp. 33783385, 2003.

S. Khayat, H. Fanaei, and A. Ghanbarzehi, "Minerals in pregnancy and lactation: A review article," J. Clin. Diagnostic Res., vol. 11, no. 9, pp. QE01-QE05, 2017.

S. Lee and S. L. Kelleher, "Molecular regulation of lactation: The complex and requisite roles for zinc," Arch. Biochem. Biophys., vol. 611, pp. 86-92, 2016.

UNICEF, "Breastfeeding on the Worldwide Agenda: Findings from a landscape analysis on political commitment for programmes to protect, promote and support breastfeeding," p. 79, 2013.

V. Lopez and S. L. Kelleher, "Zinc transporter-2 (ZnT2) variants are localized to distinct subcellular compartments and functionally transport zinc," Biochem. J., vol. 422, no. 1, pp. 43-52, 2009.

World Health Organisation, I. WHO: Maternal, and C. Health, Essential Nutrition ActionsImproving maternal, newborn, infant and young child health and nutrition. 2013.

Y. A. Seo and S. L. Kelleher, "Functional analysis of two single nucleotide polymorphisms in SLC30A2 (ZnT2): implications for mammary gland function and breast disease in women," Physiol Genomics, vol. 42A, no. 4, pp. 219-227, 2010. 